\title{
Analisis Pushoverterhadap Variasi Penempatan High Damping Rubber Bearing (HDRB) pada Struktur Gedung Bertingkat
}

\author{
Tazha Arifin ${ }^{1}$ and Erma Desmaliana ${ }^{1 *}$ \\ Dikirim: 16/09/2021 \\ Diterima: 17/09/2021
}

\begin{abstract}
ABSTRAK
High Damping Rubber Bearing (HDRB) merupakan salah satu jenis isolator yang digunakan dalam perancangan struktur gedung tahan gempa, biasanya ditempatkan pada dasar bangunan dan berfungsi untuk meredam gaya gempa. Penelitian ini bertujuan untuk mengetahui respon struktur berupa gaya geser dasar dan simpangan antar lantai, serta tingkat kinerja struktur gedung bertingkat terhadap variasi penempatan HDRB menggunakan metode analisis pushover dengan bantuan software ETABS. Struktur gedung beton bertulang 12 lantai, dengan tinggi tiap lantai $4 \mathrm{~m}$. Variasi penempatan HDRB pada model 1 di dasar gedung, pada model 2 di lantai pertama dan pada model 3 di tengah-tengah gedung. Standar analisis mengacu pada SNI 1726:2019 dan ATC-40. Hasil penelitian menunjukkan bahwa gaya geser dasar maksimum yang paling menentukan dari ketiga model struktur gedung bertingkat yang terbesar, yaitu $2.566,78 \mathrm{kN}$ dengan perpindahan maksimum 0,35 m. Tingkat kinerja berdasarkan ATC-40 termasuk dalam kategori aman yaitu Immediate Occupancy (IO). Berdasarkan SNI 1726:2019 memenuhi batasan simpangan antar lantai izin.
\end{abstract}

Kata kunci: high damping rubber bearing, analisis pushover, tingkat kinerja struktur

\section{PENDAHULUAN}

Isolator memiliki beberapa jenis, salah satunya adalah High Damping Rubber Bearing (HDRB). HDRB berfungsi meredam gaya lateral di dasar bangunan sehingga bangunan akan menerima sedikit gaya lateral yang terjadi. Gaya lateral atau juga gaya gempa rencana ini dalam analisis bisa disederhanakan sebagai gaya geser dasar struktur yang dihasilkan setelah melakukan running analysis pada software ETABS. Fungsi lain dari HDRB ini adalah membuat penghuni bangunan tetap aman dan nyaman walau terjadi gempa. Sebelum adanya teknologi isolator ini, cara untuk membuat struktur tahan gempa adalah dengan membangun bangunan tahan gempa konvesional, yaitu mengandalkan kekuatan bahan bangunannya [1].

Penempatan peredam gempa biasanya berada di dasar bangunan tepatnya dipasang diantara fondasi dan kolom, akan tetapi variasi penempatan lain pun bisa digunakan karena ada faktor lain yang bisa dipertimbangkan, seperti kurangnya lahan yang akan digunakan dan pertimbangan arsitektural, fungsi struktur yang akan digunakan. Penggunaan isolator pada struktur gedung bisa mereduksi perpindahan lantai hingga 30\%. Adanya pengurangan perpindahan lantai ini bisa juga dijadikan dasar untuk mengurangi kekakuan struktur gedung. Untuk gaya gempa yang terjadi, struktur yang menggunakan isolator di dasar bangunan bisa dikurangi hingga $47 \%$ gaya yang tereduksi, dimana bisa mengurangi dimensi komponen struktur yang akan digunakan [2].

\footnotetext{
${ }^{1}$ Institut Teknologi Nasional Bandung, Jl. PH.H. Mustofa No.23, Bandung 40124

*ermadesmaliana@itenas.ac.id
} 


\section{TINJAUAN PUSTAKA}

\section{Prinsip Sistem Inter-story Isolation}

Sistem Inter-story Isolation memiliki pengertian yang sama dengan Sistem Base Isolation, yaitu dimana beban gempa yang mengenai bangunan dapat direduksi dengan memasang free joint di antara struktur atas dan bawah sehingga struktur dapat bergerak horizontal pada free joint tersebut. Adapun perbedaan di antara kedua sistem tersebut yaitu penempatan free joint yang akan dianalisis. Pada sistem ini isolator bisa ditempatkan di antara lantai dari struktur bangunan. Awal mula munculnya istilah Sistem Inter-story Isolation adalah terbatasnya jumlah isolator yang akan digunakan. Pada umumnya, gedung yang menggunakan isolator pada bagian struktur di atas lapisan isolator memiliki pengaruh gaya gempa yang lebih kecil dan tingkat kekakuan dan kekuatannya lebih baik. Dengan demikian adanya kebebasan untuk perencanaan struktural dan arsitektural di atas lapisan isolator. Contohnya gedung multi-fungsi. Hal lain dari adanya sistem ini adalah biaya operasional yang kurang, karena saat isolator dipasang di antara lantai bangunan, jumlah unit isolator bisa kurang dari jumlah kolom yang ada [3].

\section{High Damping Rubber Bearing (HDRB)}

High Damping Rubber Bearing (HDRB) adalah salah satu isolator seismik yang banyak digunakan saat ini memiliki jenis karet yang lebih baik meredam gaya gempa membuat jenis ini menjadi unggulan dibanding jenis yang lain, dengan parameter yang dibandingkan dengan jenis isolator lain adalah modulus geser dan rasio redaman yang dihasilkan karet saat melakukan analisis. Material yang digunakan untuk HDRB yang utama adalah karet dan pelat baja, sesuai dengan Gambar 1 bentuk HDRB dan komponen lain yang mendukung unit HDRB. Kegunaan karet untuk material HDRB adalah agar karet bisa mengikuti pergerakan horizontal dan pelat baja membantu karet agar tidak mengembung ke samping karena adanya beban dari bangunan di atasnya.

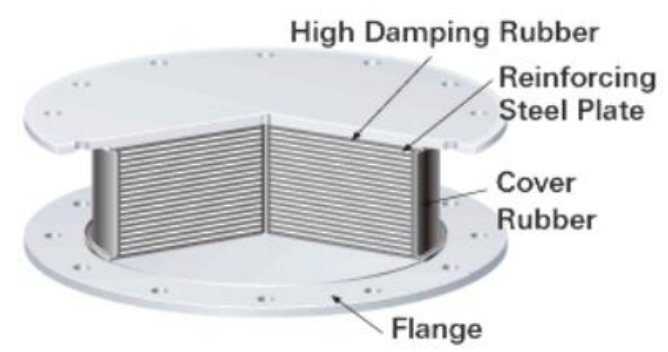

Gambar 1. Komposisi High Damping Rubber Bearing (HDRB)

\section{Perancangan High Damping Rubber Bearing (HDRB)}

Pada penelitian ini struktur menggunakan dua tipe HDRB dengan diameter yang berbeda yaitu, diameter $650 \mathrm{~mm}$ dan $700 \mathrm{~mm}$. Spesifikasi pada analisis ini mengacu pada produk dari pabrik Bridgestone 2015. Hasil studi Samasya, I. (2017) Neim \& Kelly menyatakan untuk dimensi HDRB menggunakan Persamaan (1) dan Persamaan (2).

$$
K_{H}=W \times\left(\frac{2 \pi}{T_{D}}\right)^{2}
$$

dengan $\mathrm{K}_{\mathrm{H}}$ menunjukkan kekakuan struktur, $\mathrm{W}$ menunjukkan berat per-struktur kolom, dan $\mathrm{T}_{\mathrm{D}}$ menunjukkan periode getar rencana.

$$
K_{H^{\prime}}=\frac{G \times A}{t_{r}}
$$

dengan $\mathrm{K}_{\mathrm{H}^{\prime}}$ menunjukkan kekakuan elastomer, $\mathrm{G}$ menunjukkan modulud geser elastomer, $\mathrm{A}$ menunjukkan luas elastomer, dan $t_{r}$ menunjukkan tebal elastomer. 
Setelah disederhanakan antara Persamaan (1) dan Persamaan (2) didapatkan Persamaan (3) untuk mendapatkan luas elastomer atau unit HDRB dan setelahnya bisa menentukan diameter yang sesuai dengan spesifikasi yang ada di brosur pabrik Bridgestone 2015.

$$
A=\frac{W \times\left(\frac{2 \pi}{T_{D}}\right)^{2}}{G \times A} \times t_{r}
$$

Penempatan HDRB pada model 3 menggunakan isolator dengan diameter $650 \mathrm{~mm}$, sedangkan pada model 1 dan model 2 menggunakan isolator yang berdiameter $700 \mathrm{~mm}$, hal ini mengikuti dimensi kolom yang digunakan. Spesifikasi HDRB yang digunakan pada penelitian ini tertera pada Tabel 1 berikut.

Tabel 1. Spesifikasi High Damping Rubber Bearing (HDRB)

\begin{tabular}{ccccc}
\hline $\begin{array}{c}\text { Jenis } \\
\text { HDRB }\end{array}$ & $\begin{array}{c}\text { D } \\
{[\mathbf{m m}]}\end{array}$ & $\begin{array}{c}\text { Kekakuan Awal } \\
{[\mathbf{k N} / \mathbf{m}]}\end{array}$ & $\begin{array}{c}\text { Kekakuan Efektif } \\
{[\mathbf{k N} / \mathbf{m}]}\end{array}$ & $\begin{array}{c}\text { Rasio Redaman } \\
\text { Efektif }\end{array}$ \\
\hline HH065X.6R & 650 & 6.150 & 1.040 & 0,24 \\
HH070X.6R & 700 & 6.990 & 1.180 & 0,24 \\
\hline
\end{tabular}

Penempatan isolator pada penelitian ini memiliki 3 variasi, model 1 isolator ditempatkan di dasar gedung seperti Gambar 2, Gambar 3 berupa model 2 isolator ditempatkan pada lantai pertama, dan untuk Gambar 4 berupa model 3 isolator ditempatkan di tengah-tengah gedung.

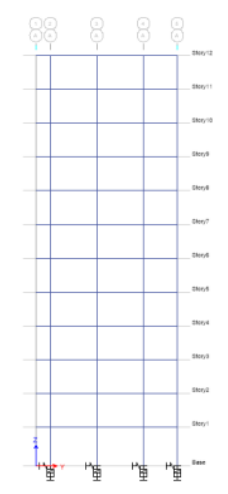

Gambar 2. Penempatan Model 1

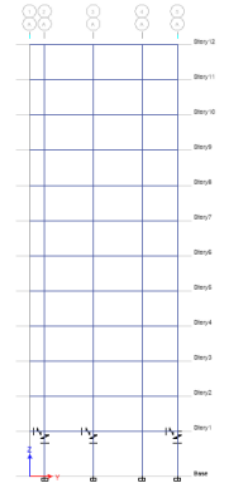

Gambar 3. Penempatan Model 2

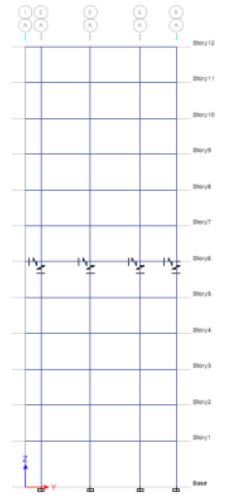

Gambar 4. Penempatan

Model 3

\section{Analisis Statik Beban Dorong (Static Pushover Analysis)}

Analisis statik beban dorong atau juga disebut Static Pushover Analysis merupakan suatu analisis statik nonlinier, halmana pengaruh gempa rencana terhadap struktur gedung dianggap sebagai beban-beban statik yang merangkap pada pusat massa masing-masing lantai, yang nilainya ditingkatkan secara berangsur-angsur hingga melampaui pembebanan yang menyebabkan terjadinya pelelehan atau sendi plastis pertama dalam struktur gedung. Saat beban-beban terus ditingkatkan, maka gedung akan mengalami perubahan bentuk pasca elastis yang besar hingga mencapai kondisi plastis. Pushover Analysis juga bertujuan untuk mengevaluasi perilaku seismik struktur gedung terhadap gempa rencana, yaitu dengan memperoleh nilai $\mu_{\Delta}, R$ aktual struktur, dan distibusi sendi plastis [4]. Untuk penyederhaan bisa dengan mengumpulkan 3 (tiga) informasi elemen penting yaitu, kurva kapasitas, kurva demand, dan titik kinerja struktur.

\section{METODOLOGI PENELITIAN}

Tahap pertama yang dilakukan dalam penelitian ini yaitu mengidentifikasi masalah dan menentukan topik yang akan ditinjau, serta melakukan tinjauan pustaka yang akan digunakan sebagai dasar analisis yang akan dilakukan. Tahap kedua yaitu menentukan layout dan dimensi 
struktur gedung, serta dilanjutkan dengan preliminary design HDRB. Tahap ketiga yaitu memasukkan data struktur gedung dan pembebanan pada software ETABS sesuai dengan SNI 1727:2020 mengenai Beban Minimum untuk Perencanaan Bangunan Gedung dan Struktur Lain. Dalam penelitian ini, fungsi struktur gedung adalah sebagai kantor dan tempat tinggal. Tahap selanjutnya yaitu pemodelan struktur gedung dengan 3 variasi penempatan isolator, yaitu model 1 ditempatkan di antara fondasi dan kolom lantai satu, model 2 ditempatkan di atas kolom lantai satu, dan variasi ketiga ditempatkan di kolom tengah bangunan atau antara kolom lantai 6 dan kolom lantai 7. Analisis struktur yang dilakukan meliputi periode struktur, jumlah ragam getar struktur, ketidakberaturan struktur, gaya geser dasar, simpangan antar lantai dan pengaruh PDelta. Tahap terakhir yaitu mengevalusi tingkat kinerja struktur menggunakan analisis pushover.

\section{HASIL DAN PEMBAHASAN}

\section{Perancangan Struktur Gedung}

Data perancangan struktur gedung yang digunakan dalam penelitian ini yaitu lokasi gedung berada di Kota Bandung, fungsi gedung sebagai kantor dan rumah tinggal, serta tinggi tiap lantai $4 \mathrm{~m}$ dari lantai dasar hingga atap. Sistem struktur gedung termasuk sistem rangka pemikul momen khusus (SRPMK) beton bertulang, dengan mutu beton $\left(f_{c}\right)$ sebesar $30 \mathrm{MPa}$ dan mutu baja tulangan $\left(f_{y s}\right)$ sebesar $420 \mathrm{MPa}$. Struktur gedung memiliki nilai koefisien modifikasi respons (R) sebesar 8 dan nilai faktor keutamaan gempa $\left(l_{e}\right)$ sebesar 1,0.

\section{Preliminary Design}

Perhitungan dimensi balok, kolom dan pelat mengikuti aturan dari SNI 2847:2019 mengenai Persyaratan Beton Struktural untuk Bangunan Gedung. Adapun data elemen struktur gedung terlihat pada Tabel 2 hingga Tabel 4.

Tabel 2. Dimensi Balok Struktur Gedung

\begin{tabular}{ccccc}
\hline Elemen Struktur & Arah & Panjang Bentang [mm] & Lebar [mm] & Tinggi [mm] \\
\hline Balok Induk & X & 6.000 & 600 & 700 \\
Balok Induk & Y & 4.800 & 500 & 600 \\
Balok Induk & Y & 3.500 & 250 & 350 \\
Balok Anak & X & 3.000 & 200 & 300 \\
Balok Anak & X & 1.500 & 100 & 200 \\
Balok Anak & Y & 2.400 & 150 & 250 \\
\hline
\end{tabular}

Tabel 3. Dimensi Kolom Struktur Gedung

\begin{tabular}{ccccc}
\hline Elemen Struktur & Lantai & Tinggi Lantai [mm] & Lebar [mm] & Tinggi [mm] \\
\hline Kolom & $1-6$ & 4.000 & 700 & 700 \\
Kolom & $7-12$ & 4.000 & 650 & 650 \\
\hline
\end{tabular}

Tabel 4. Dimensi Pelat Struktur Gedung

\begin{tabular}{ccc}
\hline Elemen Struktur & Lantai & Tebal [mm] \\
\hline Pelat Lantai & $1-11$ & 150 \\
Pelat Atap & 12 & 120 \\
\hline
\end{tabular}

\section{Periode Struktur}

Periode struktur merupakan waktu bergetar dan bergoyangnya struktur dalam satu periode. Periode struktur harus memenuhi persyaratan SNI 1726:2019 supaya kondisi struktur tidak terlalu fleksibel. Hasil periode struktur gedung dengan HDRB untuk setiap varian yang dianalisis 
memberikan nilai yang beragam. Pada model 1 nilai periode struktur lebih besar dibandingkan struktur gedung tanpa HDRB, pada model 2 nilai periode struktur lebih kecil dibandingkan nilai periode struktur model 1, pada model 3 nilai periode struktur paling kecil di antara semua model struktur gedung. Perbedaan nilai periode struktur yang dianalisis akibat penempatan HDRB yang tidak di dasar bangunan. Adapun nilai periode struktur hasil analisis tersaji pada Gambar 5.

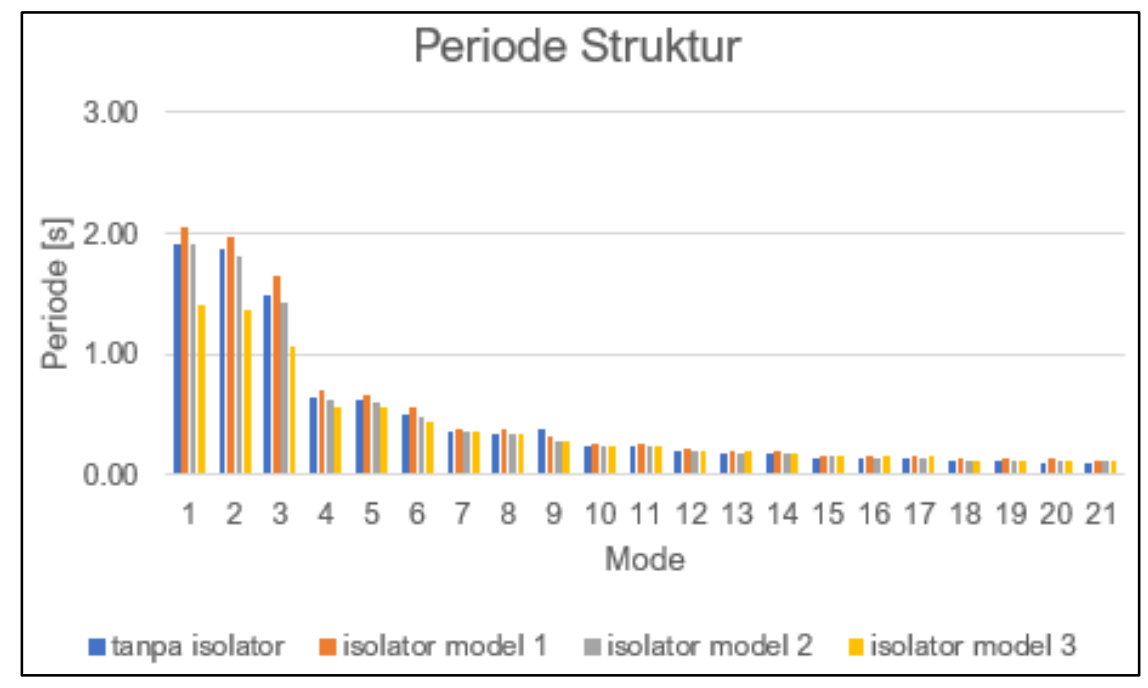

Gambar 5. Periode Struktur Gedung

\section{Jumlah Ragam Getar Struktur}

Berdasarkan SNI 1726:2019 jumlah ragam getar struktur harus cukup untuk memperoleh rasio modal partisipasi massa terkombinasi paling sedikit sebesar $100 \%$ dari massa aktual pada arah $X$ dan arah $\mathrm{Y}$, sehingga dapat menentukan ragam getar struktur pada gedung. Berdasarkan hasil analisis menujukkan bahwa periode struktur dan jumlah ragam getar struktur diperoleh dari 21 mode shapes seperti tersaji pada Gambar 6.

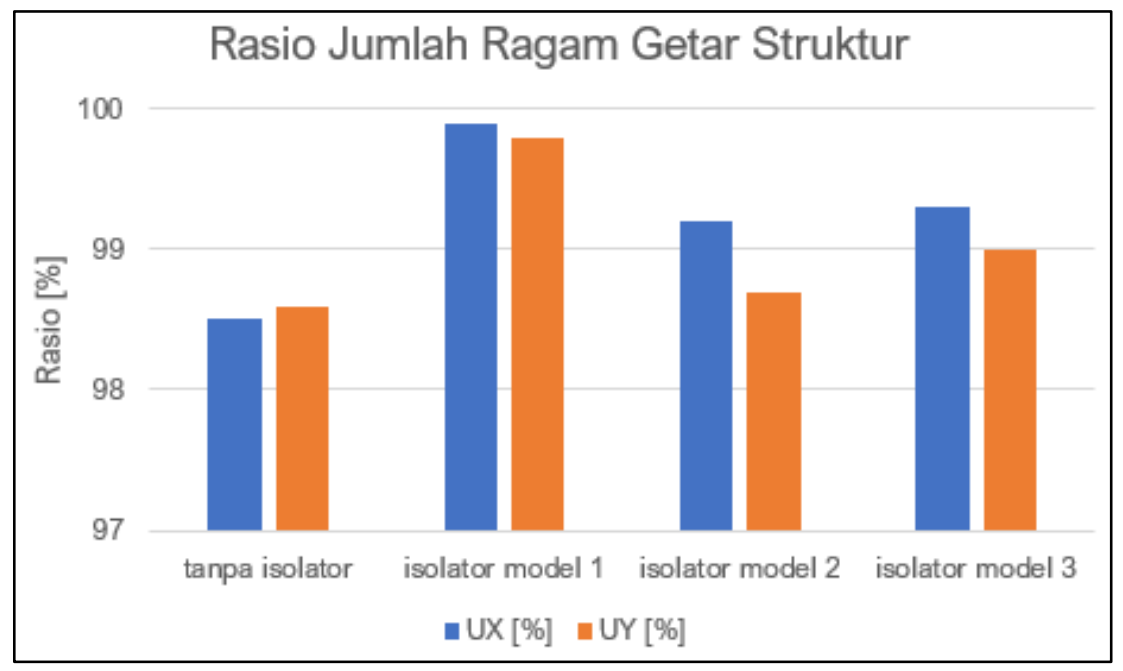

Gambar 6. Rasio Jumlah Ragam Getar Struktur

\section{Ketidakberaturan Struktur}

Struktur gedung harus diklasifikasikan sebagai struktur beraturan atau tidak beraturan, hal ini berdasarkan kriteria-kriteria yang telah ditetapkan dalam SNI 1726:2019. Ketidakberaturan struktur gedung yang ditinjau dalam penelitian ini yaitu ketidakberaturan horizontal Tipe 1.a. Berdasarkan SNI 1726:2019, struktur gedung termasuk beraturan jika nilai rasio simpangan antar 
lantai untuk arah $\mathrm{X}$ maupun $\mathrm{Y}$ kurang dari 1,2. Berdasarkan hasil analisis menggunakan software ETABS menunjukkan bahwa struktur gedung yang diteliti termasuk kategori beraturan karena nilai rasio simpangan antara lantainya kurang dari 1,2.

\section{Gaya Geser Dasar}

Gaya geser dasar didistribusikan secara vertikal sepanjang tinggi struktur gedung sebagai gaya horizontal tingkat yang bekerja pada masing-masing tingkat gedung dengan menjumlahkan gaya horizontal pada tingkat-tingkat yang ditinjau. Nilai gaya geser dasar dipengaruhi oleh besaran nilai periode struktur, halmana semakin besar nilai periode struktur maka nilai gaya geser dasar semakin kecil dan begitu pun sebaliknya. Adapun nilai gaya geser dasar hasil analisis tersaji pada Tabel 5.

Tabel 5. Gaya Geser Dasar

\begin{tabular}{ccccc}
\hline \multicolumn{5}{c}{ V [kN] } \\
\hline Arah & Tanpa Isolator & Isolator Model 1 & Isolator Model 2 & Isolator Model 3 \\
\hline $\mathrm{X}$ & $1.057,57$ & $1.053,99$ & $1.993,45$ & $2.566,78$ \\
$\mathrm{Y}$ & $1.081,33$ & $1.077,66$ & $1.929,03$ & $2.562,64$ \\
\hline
\end{tabular}

\section{Simpangan Antar Lantai}

Berdasarkan hasil analisis, nilai simpangan antar lantai (story drift) pada keempat model struktur gedung tanpa dan dengan HDRB mengalami peningkatan dan penurunan disebabkan adanya variasi penempatan HRDB, seperti tersaji pada Gambar 7 dan Gambar 8.

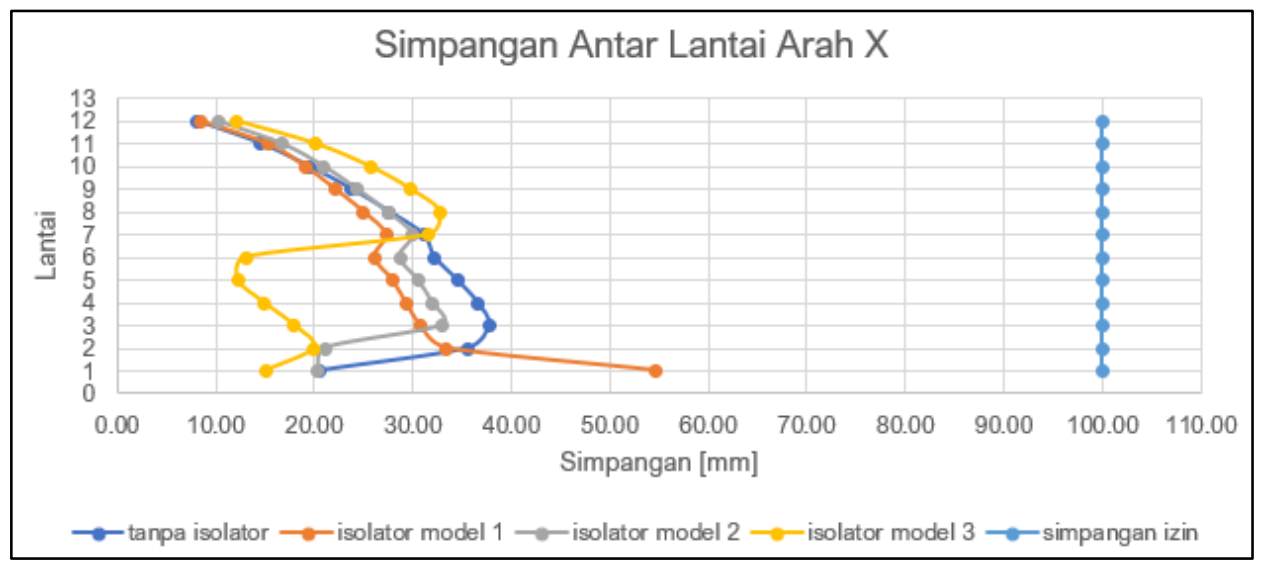

Gambar 7. Simpangan Antar Lantai Struktur Gedung Arah X

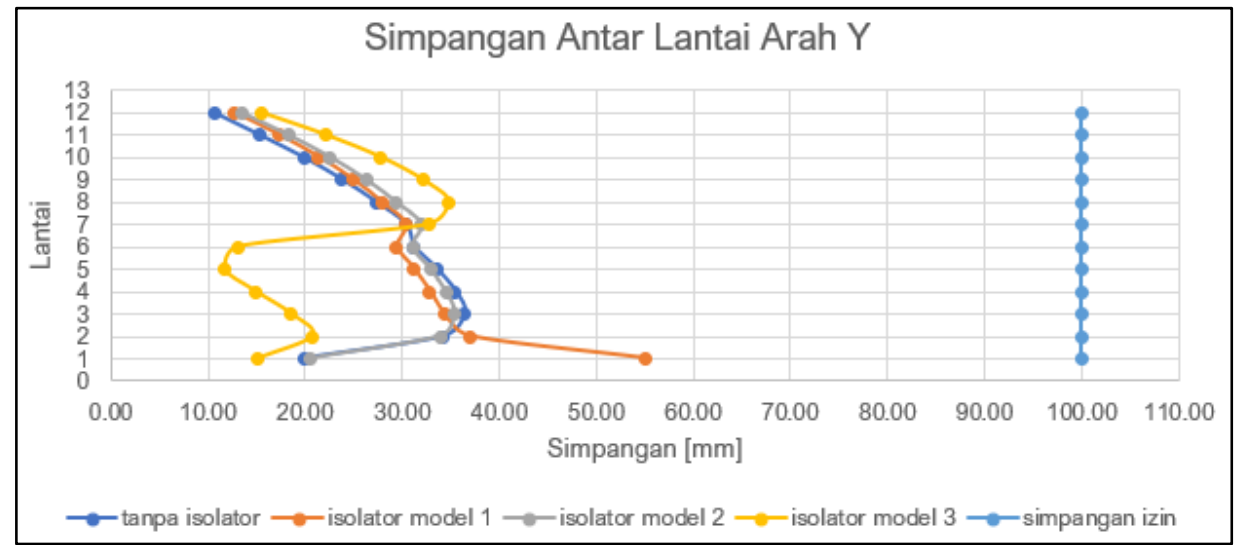

Gambar 8. Simpangan Antar Lantai Struktur Gedung Arah Y 


\section{Pengaruh P-Delta}

Koefisien stabilitas dinyatakan oleh nilai $\theta$, nilai $\theta$ untuk semua model struktur gedung tanpa dan dengan variasi penempatan HDRB berdasarkan hasil analisis masih berada di bawah nilai $\theta_{\text {maksimum }}$ sebesar 0,09 sehingga struktur gedung disimpulkan masih stabil. Dengan kata lain, variasi penempatan HDRB tidak terlalu mempengaruhi efek P-Delta. Adapun pengaruh P-Delta hasil analisis tersaji pada Gambar 9 dan Gambar 10.

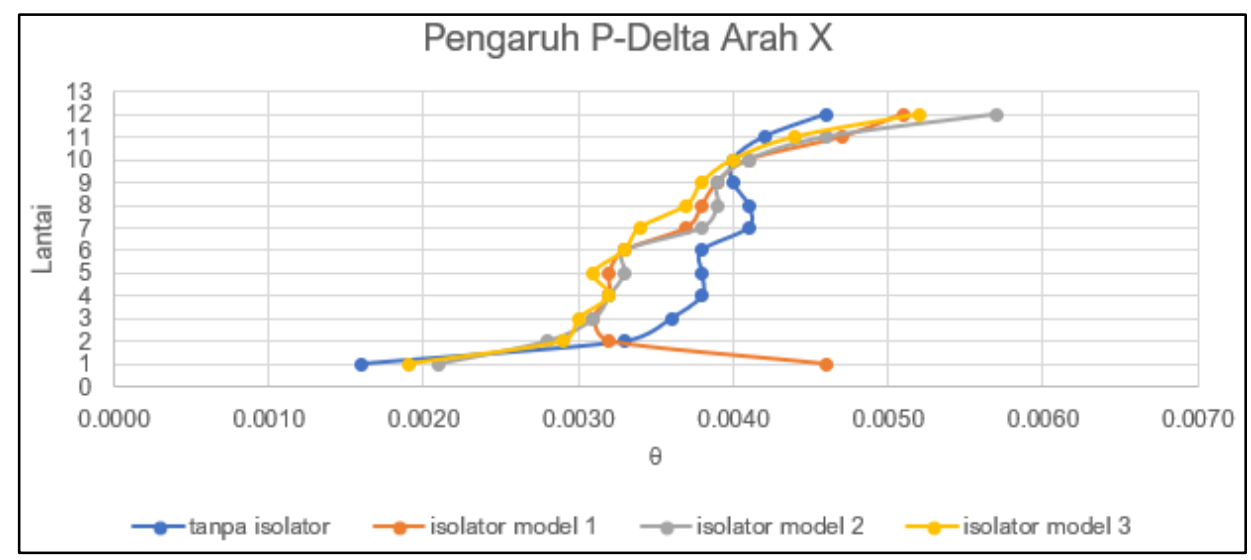

Gambar 9. Pengaruh P-Delta Arah X

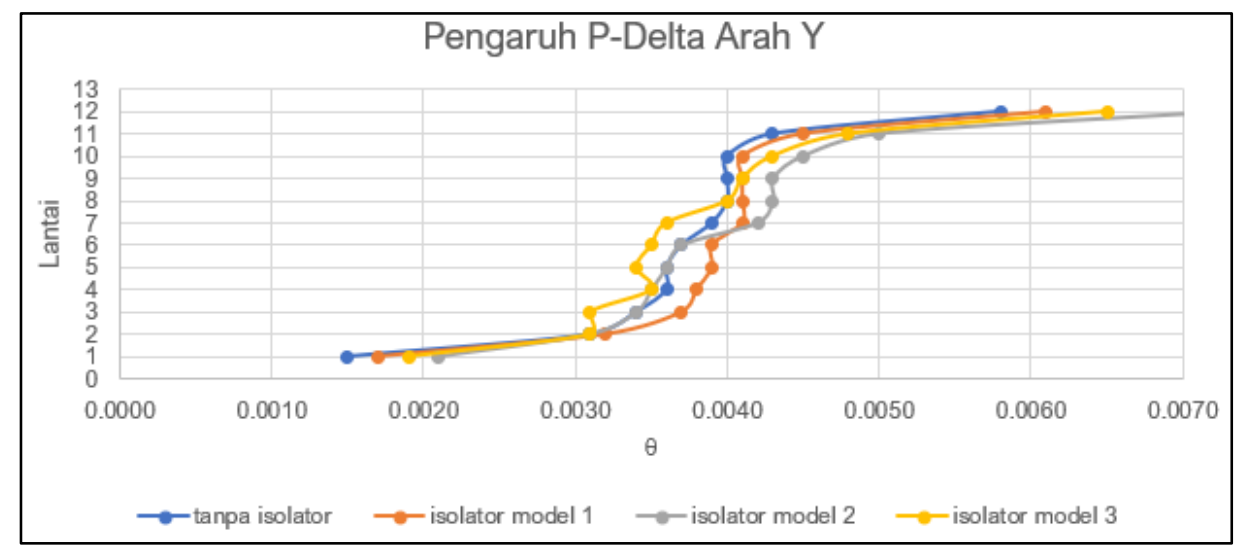

Gambar 10. Pengaruh P-Delta Arah Y

\section{Tingkat Kinerja Struktur}

Berdasarkan hasil analisis pushover, tingkat kinerja struktur gedung diperoleh dari gabungan 3 (tiga) informasi elemen penting yaitu kurva kapasitas, kurva demand dan titik kinerja. Titik kinerja diperoleh dari perpotongan antara kurva kapasitas dan kurva demand. Berikut hasil analisis tingkat kinerja yang disajikan pada Tabel 6 .

Tabel 6. Tingkat Kinerja Struktur

\begin{tabular}{cc}
\hline Jenis Struktur Gedung & Tingkat Kinerja \\
\hline Tanpa Isolator & IO - LS \\
Isolator Model 1 & IO - LS \\
Isolator Model 2 & IO - LS \\
Isolator Model 3 & IO \\
\hline
\end{tabular}


Gambar 11 menunjukkan grafik hubungan kurva kapasitas dan kinerja struktur baik arah $\mathrm{X}$ maupun arah $\mathrm{Y}$ untuk struktur gedung bertingkat tanpa HDRB. Serta, posisi titik kinerja struktur gedung berada, yaitu antara batas IO (Immediate Occupancy) dan LS (Life Safety).
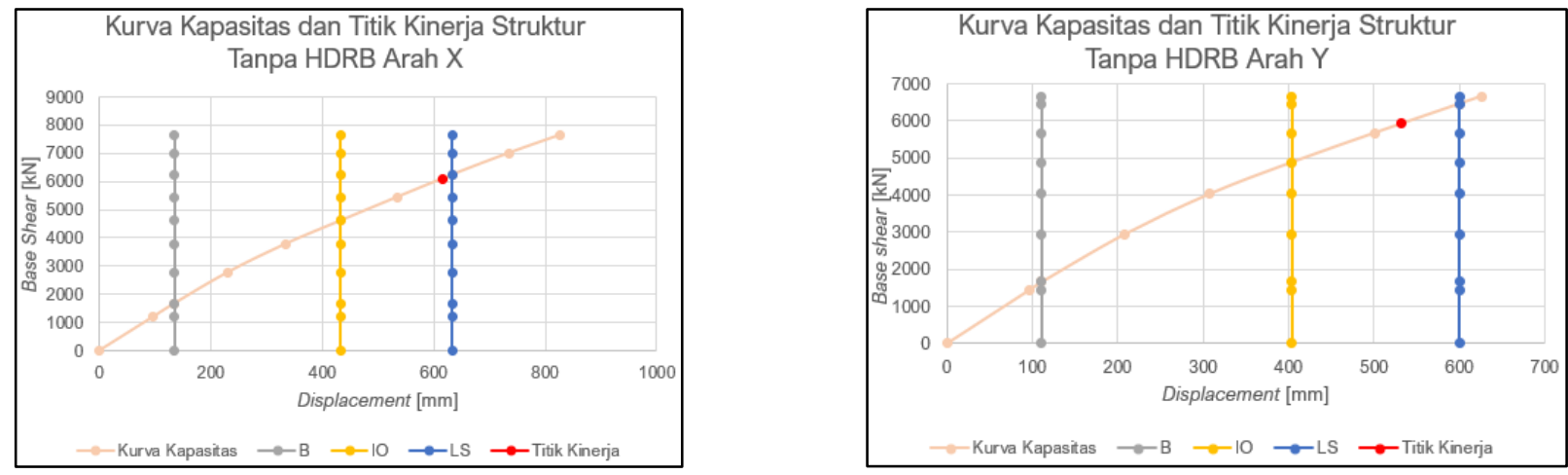

Gambar 11. Kurva Kapasitas dan Titik Kinerja Struktur Tanpa HDRB

Gambar 12 menunjukkan grafik hubungan kurva kapasitas dan kinerja struktur baik arah $\mathrm{X}$ maupun arah $Y$ untuk struktur gedung bertingkat dengan HDRB model 1. Serta, posisi titik kinerja struktur gedung berada, yaitu antara batas IO (Immediate Occupancy) dan LS (Life Safety).
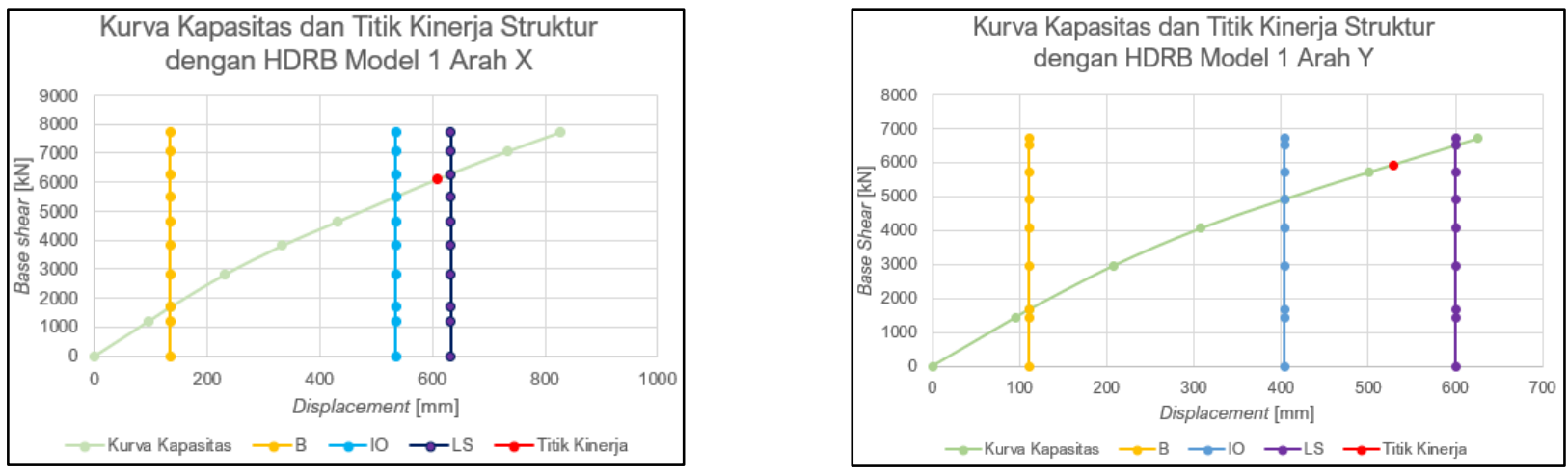

Gambar 12. Kurva Kapasitas dan Titik Kinerja Struktur dengan HDRB Model 1

Gambar 13 menunjukkan grafik hubungan kurva kapasitas dan kinerja struktur baik arah $\mathrm{X}$ maupun arah $Y$ untuk struktur gedung bertingkat dengan HDRB model 2. Serta, posisi titik kinerja struktur gedung berada, yaitu antara batas IO (Immediate Occupancy) dan LS (Life Safety).
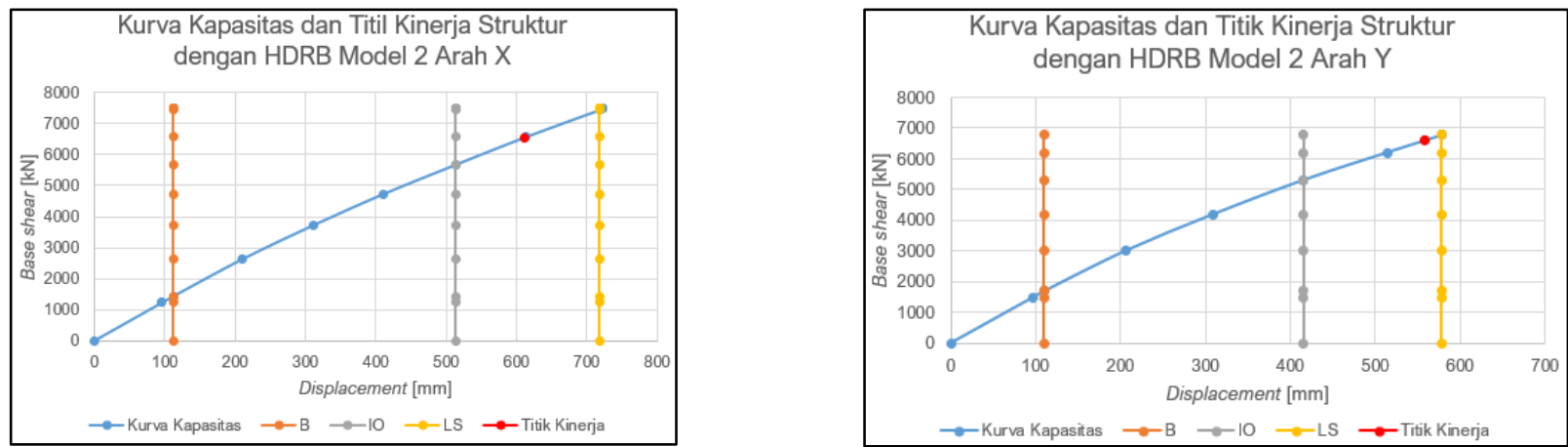

Gambar 13. Kurva Kapasitas dan Titik Kinerja Struktur dengan HDRB Model 2

Gambar 14 menunjukkan grafik hubungan kurva kapasitas dan kinerja struktur baik arah $\mathrm{X}$ maupun arah $Y$ untuk struktur gedung bertingkat dengan HDRB model 3. Serta, posisi titik kinerja 
struktur gedung berada, yaitu IO (Immediate Occupancy) untuk arah X dan antara batas IO (Immediate Occupancy) dan LS (Life Safety) untuk arah Y.
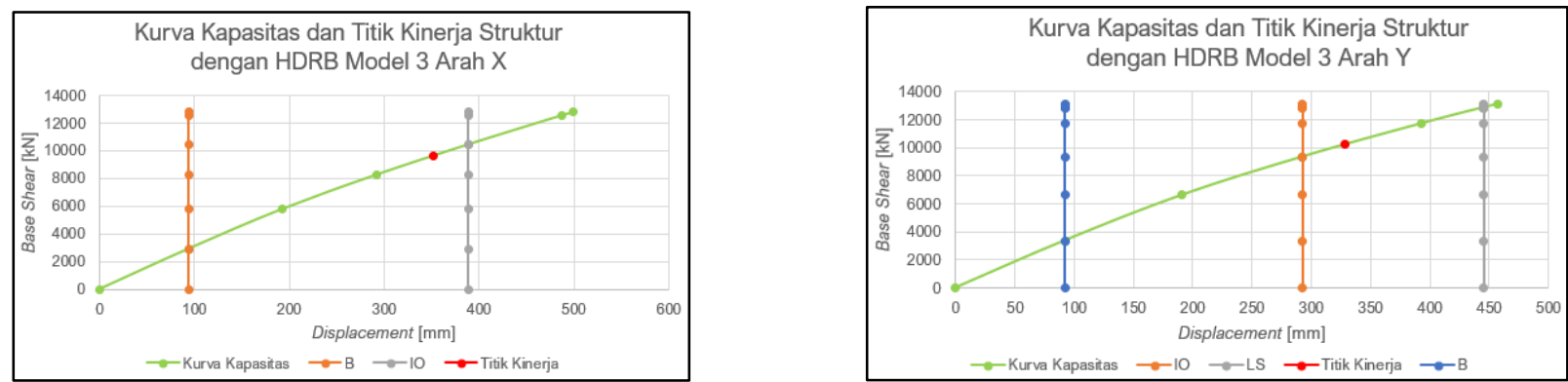

Gambar 14. Kurva Kapasitas dan Titik Kinerja Struktur dengan HDRB Model 3

\section{KESIMPULAN}

Berdasarkan hasil analisis dan pembahasan yang telah dilakukan untuk ketiga model struktur gedung baik terhadap beban gempa maupun beban statik dorong (pushover), maka dapat ditarik kesimpulan sebagai berikut:

1) Nilai periode struktur gedung model 1 paling besar karena adanya HDRB di dasar gedung. HDRB lebih efektif untuk meredam gaya gempa dengan penempatan di dasar gedung dibandingkan model 2 dan model 3. Nilai periode struktur gedung model 2 dan 3 mengalami penurunan sebesar $7,14 \%$ dan $31,37 \%$ terhadap model 1 . Hal ini mengakibatkan struktur gedung model 2 dan model 3 lebih kaku ketika terjadi gempa bumi.

2) Nilai gaya geser dasar menggunakan variasi penempatan HDRB mengalami peningkatan sebesar $43,94 \%$ untuk struktur gedung model 2 dan $57,80 \%$ untuk struktur gedung model 3 . Hal ini berbanding terbalik dengan struktur gedung model 1, nilai gaya geser dasar mengalami penurunan sebesar $0,34 \%$.

3) Nilai simpangan antar lantai struktur gedung model 1 secara keseluruhan lebih kecil dibandingkan dengan model 2 dan model 3. Hal ini dikarenakan pengaruh dari nilai respons struktur lain yang berkurang dari biasanya. Seluruh model struktur gedung sudah memenuhi persyaratan simpangan antar lantai izin maksimum yaitu $100 \mathrm{~mm}$.

4) Pengaruh P-Delta menunjukkan kestabilan suatu struktur gedung dalam menahan gempa bumi disimbolkan dengan nilai $\theta$. Nilai $\theta$ seluruh model struktur gedung sudah memenuhi persyaratan $\theta_{\max }$ yaitu 0,09.

5) Berdasarkan hasil analisis yang telah dilakukan, terdapat peningkatan jumlah ragam getar struktur untuk arah translasi horizontal sumbu $X$ dan sumbu $Y$ menggunakan HDRB dengan tiga variasi penempatan. Hal ini membuktikan bahwa struktur gedung dengan variasi penempatan HDRB membutuhkan waktu yang lebih singkat dibandingkan tanpa HDRB untuk mencapai rasio massa partisipasi modal sesuai SNI 1726:2019 yaitu mencapai 100\%.

6) Ketidakberaturan struktur gedung yang dianalisis menyatakan bahwa struktur gedung baik tanpa HDRB maupun dengan tiga variasi penempatan HDRB termasuk dalam kategori struktur yang beraturan. Hal itu dibuktikan dengan nilai rasio simpangan antar lantai struktur gedung semua model kurang dari 1,2 sehingga sudah memenuhi pesyaratan SNI 1726:2019 untukmenyatakan bahwa struktur gedung tidak memiliki ketidakberaturan horizontal tipe 1.a.

7) Hasil analisis di atas menyimpulkan bahwa tingkat kinerja struktur gedung bertingkat 12 lantai dengan variasi penempatan HDRB yaitu Immediate Occupancy (IO) halmana tingkat kinerja struktur ini mengindikasikan kondisi struktur gedung tidak mengalami kerusakan yang berarti ketika dibebani gempa sehingga struktur gedung masih tetap dapat berfungsi selayaknya tanpa terganggu masalah perbaikan sesuai dengan ATC-40.

\section{DAFTAR RUJUKAN}

[1] I.K. Sulendra., "Evaluasi dan Tindakan Pengurangan Kerusakan Bangunan Berdasarkan 
Peta Zonasi Gempa Tahun 2010." 2017, [Daring]. Tersedia pada: media.neliti.com/media/publications/242905-evaluasi-dan-tindakan-pengurangan-kerusa051203e5.pdf.

[2] F.A. Ismail, "Pengaruh Penggunaan Seismic Base Isolation System terhadap Respons Struktur Gedung Ibis Padang." 2012.

[3] P. Thakur, S.K. Sethy, \& M.K. Dubey, "Inter Story Isolation System." 2019.

[4] Y.A. Pranata \& D. Simanta, "Studi Analisis Beban Dorong untuk Gedung Beton Bertulang." 2006. 